\title{
The growth of space science in African countries for Earth observation in the 21st century
}

AUTHORS:

Luncedo Ngcofe $^{1}$

Keith Gottschalk ${ }^{2}$

\section{AFFILIATIONS:}

${ }^{1}$ Council for Geoscience,

Cape Town, South Africa

2Department of Political Studies, University of the Western Cape, Cape Town, South Africa

\section{CORRESPONDENCE TO: Luncedo Ngcofe}

\section{EMAIL:}

Lngcofe@geoscience.org.za

\section{POSTAL ADDRESS:}

Council for Geoscience, PO Box 572, Bellville 7535, South Africa

\section{KEYWORDS:}

climate change; environmental monitoring; international collaboration; satellite; South Africa

\section{HOW TO CITE:}

Ngcofe L, Gottschalk K. The growth of space science in African countries for Earth observation in the 21st century. S Afr J Sci. 2013;109(1/2), Art \# a001, 5 pages. http://dx.doi. org/10.1590/sajs.2013/a001

\section{(C) 2013. The Authors.}

Published under a Creative Commons Attribution Licence.

\begin{abstract}
Earth observation is no longer just a way to satisfy our curiosity, but has become crucial in ensuring the survival of humankind (South Africa's Minister of Science and Technology, Mosibudi Mangena, 2007).
\end{abstract}

The vulnerability of Africa to the impact of climate change, which results in natural disasters and environmental degradation, accelerates hardship and poverty for millions of Africans. However, Africa still lacks the necessary scientific and technical capacity to assess fully and to monitor the possible future impacts of climate change. One of the instruments available to address the challenges of environmental monitoring (including climate change) and to provide early warnings of natural and human-made disasters for Africa's development is Earth observation satellites. Earth observation satellites record Earth's information from space and provide accurate, continuous, simultaneous measurements of our planet. The results of the application of Earth observation satellites have longterm social benefits which include the early detection of hurricanes and typhoons that can lead to prompt warnings for areas predicted to be affected, thus providing crucial time to implement safety measures to mitigate the effects of such disasters. Several authors concur with this position, stating that the global view from satellite observation is unmatched in its ability to capture the dynamics and variability of Earth processes. The capability to predict weather (among other things) has led Earth observation satellites to become essential to everyday applications that improve human safety and quality of life. However, despite the many benefits of the use of Earth observation satellites, it still remains a major challenge for Africa to explore the full potential of Earth observation satellites in addressing continental needs (Figure 1). ${ }^{1}$ This commentary assesses the status of Africa in regard to Earth observation satellites.

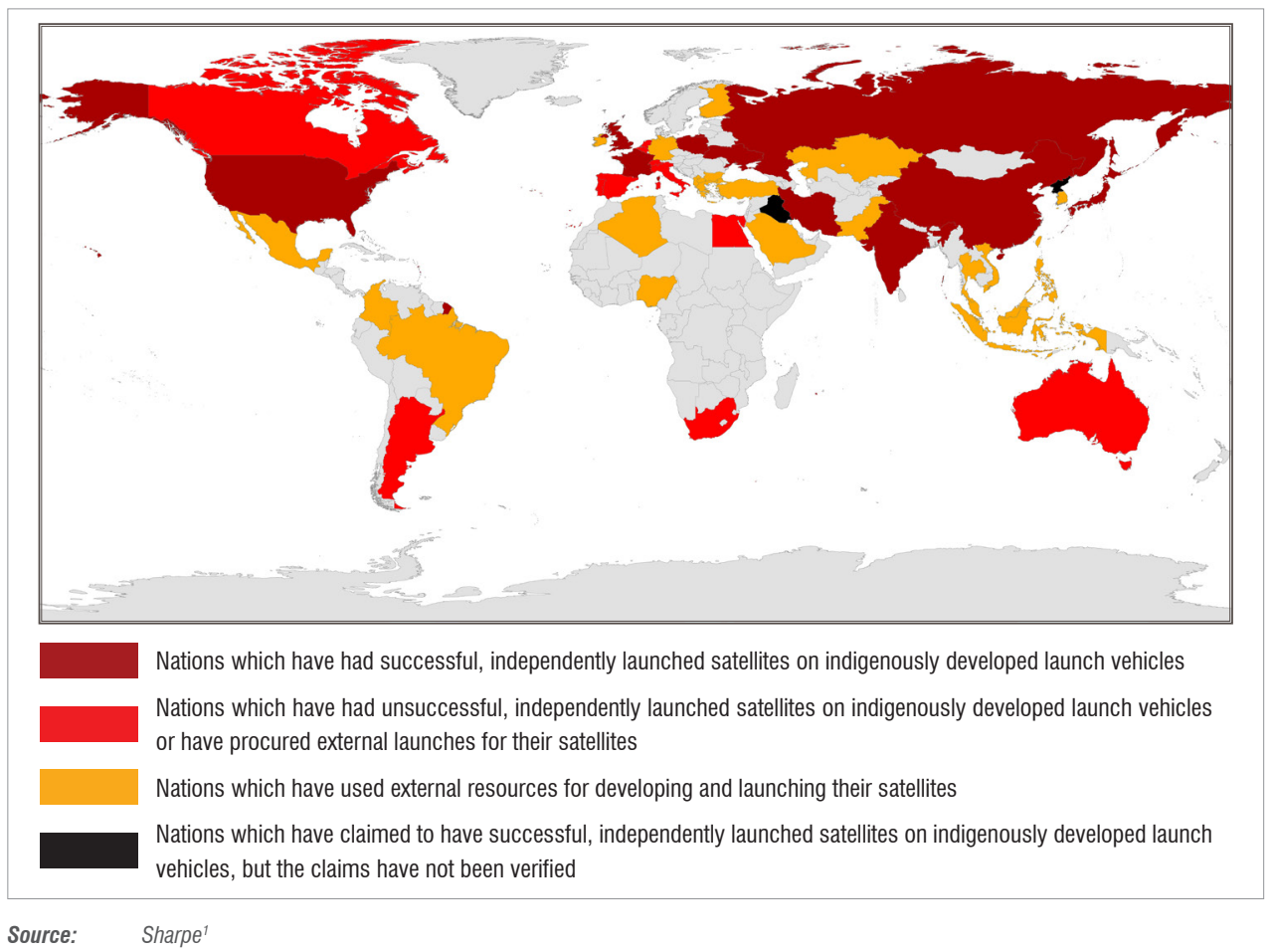

Figure 1: The status of African space activities with regard to other countries

\section{Earth observation and space development in Africa}

African countries are currently participating in a variety of notable space technology initiatives. We have chosen, however, to focus on Africa's role in Earth observation. Africa is regarded as both a collector and a user of data for and from the Earth observation satellites. The notable leading African countries involved in Earth observation are South Africa, Egypt, Algeria and Nigeria.

South Africa's history with space science is well documented. ${ }^{2-6}$ The country's involvement in space science can be traced back to the 1950s to amateur rocket launch activities. Major activities in South Africa's participation in space science really expanded after 1994 when South Africa was democratised. The end of apartheid opened new doors for South Africa to participate more effectively towards space science initiatives.

It was in 1995 that the Department of Trade and Industry and the Department of Science and Technology drafted South Africa's first space policy and strategy to manage and control space affairs in the country. This initiative led to the launch of the South African National Space Agency (SANSA) in 2011. One of SANSA's major objectives is 
to promote cooperation on space-related projects between South Africa and the international community in order to fast track South Africa's role in international space activities. Space activities after 1994 led to the launch of South Africa's first Earth observation satellite, called Sunsat, by Stellenbosch University in 1999. This satellite was launched through a working collaboration with the United States National Aeronautics and Space Administration (NASA) agency. In 2009, South Africa developed a second satellite called SumbandilaSat (Sumbandila means 'lead the way' in Venda) to showcase its growth in Earth observation space activities. This satellite was launched through the working collaboration with the Russian space agency (RKA). These two satellites are the first microsats constructed entirely on the African continent and demonstrate South Africa's hi-tech industrial capabilities. ${ }^{5}$

Egypt has participated in space science since the early 1900s. Through its Helwan Institute of Astronomy and Geophysics, Egypt shared the discovery of planet Pluto in the $1930 \mathrm{~s}^{7}$ and participated in atmospheric aerosol studies in the 1980s. Egypt launched its first Earth observation satellite - EgyptSat-1 - in 2007. The development of EgyptSat-1 was through a working collaboration with the Ukraine. This collaboration resulted in the participation of 60 Egyptian scientists and engineers in the programme. EgyptSat-1 is not the country's first satellite: two communication satellites - the Nilesat-101 (launched in 1998) and Nilesat-102 (launched in 2000) - were the stepping stones of Egypt's space science development.

Algeria launched its first satellite, called Alsat-1, in 2002, through its space agency, Agence Spatiale Algerienne (ASAL). This satellite was designed and built by Surrey Space Technology (a British Company) with the participation of 11 Algerian specialists as part of a technological transfer programme to equip Algeria for future manufacturing of its own satellites. ASAL started a 15-year national space programme (due to run from 2006 to 2020) aimed at strengthening the country's space infrastructure and increasing the number and capabilities of its space system. Through the ASAL programme, the further development of a series of Earth observation satellites (namely Alsat-1B, Alsat-2, Alsat-3 and Alsat-4) and a communication satellite (Alcomsat-1) is planned.

Nigeria established its National Space Research and Development Agency (NASRDA) in April 1999. Through NASRDA, Nigeria entered space science and launched its first Earth observation satellite, NigerianSat-1, in 2003. Similar to Alsat-1, NigerianSat-1 was built through a working collaboration with Surrey Space Technology, which trained 15 Nigerian scientists and engineers in the development and assembly of NigerianSat- 1 as part of technology transfer. The success of NigerianSat-1 has led to further space programme development, namely the fabrication of the Nigerian communication satellite, NigComSat-1 (launched in 2007), and the second Earth observation satellite NigerianSat-2 (launched in 2011).

Table 1 provides a summary of African built, owned or leased satellites with most being Earth observation satellites, the remainder being communication satellites operated by the corporate sector for television and related purposes. Table 1 excludes the first French satellite, Asterix, launched from Hammaguir (Algeria) by a Diamant rocket, and nine Italian-launched satellites from their San Marco (Kenya) offshore platform using US rockets.

\section{Potential development for Earth observation in Africa}

Scientific endeavour is not purely utilitarian in its objectives and has important associated cultural and social values. It is also important to maintain a basic competence in 'flagship' sciences such as physics and astronomy for cultural reasons. Not to offer them would be to take a negative view of our future - the view that we are a second class nation, chained forever to the treadmill of feeding and clothing ourselves (South African White Paper on Science \& Technology, 1996).

Over half a century ago, wealthier European countries recognised that their budgets and human resources were too limited to afford the national space programmes of world powers such as the USA, Russia and, today, China and India. Alongside their national space agencies, they therefore formed a continental satellite development agency and a continental space launcher agency in 1964. These agencies were in turn merged to found the European Space Agency (ESA) in 1975. Budget constraints require even ESA to work with the USA and Russia to participate in human spaceflight and the International Space Station.

The need for Africa to develop its own African Space Agency (ASA) gained momentum, and, in 2010, the African Union approved a feasibility

Table 1: $\quad$ Summary of African satellites built, bought or leased

\begin{tabular}{l|l|l}
\hline \hline Satellite & Country or organisation & Year launched \\
\hline \hline Alsat-1 & Algeria & 2002 \\
\hline Alsat-2A & Algeria & 2010 \\
\hline EgyptSat-1 & Egypt & 2007 \\
\hline New Dawn & South Africa & 2011 \\
\hline NigComSat & Nigeria & 2007 \\
\hline NigeriaSat-1 & Nigeria & 2001 \\
\hline NigeriaSat-2 & Nigeria & 2011 \\
\hline NigeriaSat-X & Nigeria & 2011 \\
\hline Nilesat 101 & Egypt & 1998 \\
\hline Nilesat 102 & Egypt & 2003 \\
\hline Nilesat 103 (Hot Bird 4, 10) & Egypt & 2005 \\
\hline Nilesat 201 & Egypt & 2010 \\
\hline RASCOM-QAF1 RQ1 & Regional African Satellite Communication Organisation (RASCOM) & 2007 \\
\hline RASCOM-QAF1R RQ1R & RASCOM & 2010 \\
\hline Shuttleworth astronaut & South Africa & 2002 \\
\hline Sumbandila & South Africa & 2009 \\
\hline Sunsat & South Africa & 1999 \\
\hline
\end{tabular}


study for the ASA. The development of this agency will enhance the contributions of other African countries towards space science. Although this initiative is seen as a positive development for Africa's contribution towards space, Peter Martinez is cited by Augustine ${ }^{8}$ as cautioning that this idea might be premature, arguing that other African countries that have not yet participated in space endeavours need first to develop their own capabilities so that they can participate fully in the development of the ASA. However, Gottschalk ${ }^{4}$ differs, stating that the development of the ASA could provide the vehicle for the continent to negotiate better offers for satellite construction, space launches, technology transfer and infrastructure, than could individual countries alone. Attesting to this, Abiodun ${ }^{7}$ stated that space exploration is a total global engagement and therefore continents ought to have one voice towards space utilisation. Thus, working on a regional basis is no longer an option, but a necessity for development. The ASA therefore needs to be implemented to enhance Africa's contribution in space science.

The launch of the Regional African Satellite Communication Organisation (RASCOM) in 1992 created the first Pan-African space initiative. RASCOM has grown to 45 African member states. It is run through a biennial Assembly of Parties, with the Director's Board meeting quarterly. Its secretariat is in Abidjan (Côte d'Ivoire), with operation centres in Gharyan (Libya) and Douala (Cameroon) and supports phone, radio, television and Internet services. Its resilience is indicated by its survival, despite two of the three locations having been affected by civil wars. RASCOM took two decades to become fully operational, which offers a realistic time frame for future Pan-African space initiatives. This period was primarily a result of delays in intergovernmental negotiations and in implementing long-promised commitments. Further delay arose from technical failures: its first satellite, RASCOM QAF 1, launched in 2007, soon failed, with the replacement RASCOM-QAF1R launched only in 2010. RASCOM's success (from its 20 transponders) has linked 150000 villages to telecommunications services. ${ }^{9,10}$

Another potential initiative for Africa's participation in space science is through the African Resource Management (ARM) satellite constellation. Negotiations that started in 2003 took 6 years to be completed successfully. The ARM started as a data-sharing agreement between Algeria, Kenya, Nigeria and South Africa to pool their satellite imagery. ${ }^{11}$ It has been viewed as Africa's Earth observation information system. Such initiatives now receive political support from the African Union. In 2003, the African Union set up the African Ministerial Conference on Science and Technology with a Bureau \& Steering Committee in Pretoria, which identified 'Space Science Technologies' as a flagship programme. ${ }^{12,13}$

Below the apex level of heads of government, space professionals meet regularly for the multilateral initiative of the biennial African Leadership Conferences (ALC) for Space Science and Technology for Sustainable Development. These have rotated between Abuja, Nigeria (2005), Pretoria, South Africa (2007), Algiers, Algeria (2009), and Mombasa, Kenya (2011). One of the proposals that has been discussed is for an African Institute of Space Science. The proposed Institute would promote and coordinate crosscutting multidisciplinary research and applications in space science and technology to address the development needs of the region. ${ }^{14}$

Africa also continues its endeavours in space science with the assistance of already developed programmes, such as the European Earth Observation System called Global Monitoring for Environment and Security (GMES). The objective of this programme is to monitor natural resources (e.g. water), to give advance warning to decisionmakers to counter effects of climate change, to support peacekeeping operations and to provide responses to natural and human-made disasters. Because of Africa's lack of continent-wide advances in Earth observation to address societal challenges, in 2010 the African Union asked for the implementation of GMES in Africa through its European Earth Observation Systems satellite. This collaboration will increase knowledge transfer between the two continents.

The United Nations Office for Outer Space Affairs ${ }^{15-18}$ has long acknowledged that the growth of scientific knowledge and continuing development in technology are improving societal challenges, from human security to sustainable development. This office established the regional centres of space science and technology education in four regions: Asia, Africa, Latin America and the Caribbean. ${ }^{15}$ In Africa, these centres were set up in 1998 and are based in Morocco and Nigeria. The Moroccan institute serves French-speaking states and has 13 member countries: Algeria, Cameroon, Cape Verde, Central African Republic, Côte d'Ivoire, Democratic Republic of Congo, Gabon, Morocco, Mauritania, Niger, Senegal, Togo and Tunisia. The Nigerian English-based institute has 15 member countries: Cameroon, Democratic Republic of Congo, Ethiopia, Gambia, Kenya, Liberia, Malawi, Nigeria, Sierra Leone, South Africa, Sudan, Uganda, Tanzania, Zambia and Zimbabwe. This initiative equips the African continent with space science knowledge.

Another international programme is the United Nations Space-based Information for Disaster Management and Emergency Response (UNSPIDER) with regional support offices in Algeria, Nigeria and South Africa, plus the Regional Centre for Mapping of Resources in Kenya, which has, in total, 14 participating African countries. The UN-SPIDER ${ }^{19}$ aims at providing universal access to all types of space-based information and services relevant to disaster management.

The African Union has further strengthened African endeavours in space science by launching the Pan-African University. ${ }^{20}$ The Pan-African University will ultimately consist of five centres across the continent, although not all have been launched yet. One of these centres will be an institute dedicated to space science which South Africa will host. The Pan-African University will increase interest in, and Africa's participation in, Earth observation. Africa's continuing participation in the development of space science will enhance the continent's ability to address vast societal challenges.

Although this commentary is focused on Earth observation satellites for assessing Africa's space participation and development, we go a step further in Table 2 to show a representative cross-section of major ground infrastructure for space-related activities in Africa. However, the remotesensing data-processing centres for Earth observation are too numerous for inclusion in one table and are therefore omitted from Table 2.

\section{Conclusion}

The exponential growth of scientific knowledge and the continuing development in technology improves living conditions in our society. The capacity that Earth observation satellites provide to observe possible threats to life on Earth and to help mitigate them is very important for human survival and social development. Although there is a strong need for technological advancement in Earth observation, Africa is faced with tremendous challenges in relation to such developments because of a scarcity of capital. The need to justify expenditure on space-related endeavours, such as Earth observation satellites, competes with other pressing expenditure needs, such as provision of food, houses, jobs and commercial development.

Analysis indicates potential problems, as well as benefits, in proposing the timing and modalities for a continental space agency. Developing countries are prone to set up top-heavy bureaucratic structures, whose prime function is political patronage. This approach diverts scarce financial resources away from science and engineering into a bloated bill for remuneration to parasitic personnel. Furthermore, founding intergovernmental agencies requires learning multilateral ways of thinking and doing. Issues of negotiating interoperationality with software, hardware and agencies are protracted. The lessons learned from RASCOM and ARM show that this process realistically requires one to two decades to operationalise. Therefore, a balanced and rational solution is to propose that an African continental space agency grows organically out of existing agreements such as the ARM, RASCOM, and institutions such as the ALC. Individual countries can be incrementally added to ARM. RASCOM could broaden its mandate from communication satellites to Earth observation satellites and other space science research. The ALC could incrementally broaden its functions from symposiums to coordination. ${ }^{21}$

It is vitally important that the African continent should have its own Earth observation satellites because if it remains a passive consumer 
Table 2: Africa's satellite ground infrastructure

\begin{tabular}{|c|c|c|}
\hline Name or locality & Country or organisation & Facilities \\
\hline 6th of October City (near Cairo) & Egypt, Nilesat & Satellite Operations Centre \\
\hline Al-Hammam (near Alexandria) & Egypt, Nilesat & Satellite Operations Centre \\
\hline Béchar & Algeria & Sounding rocket launch site \\
\hline Douala & Cameroon, RASCOM & Satellite Operations Centre \\
\hline Gharyan & Libya, RASCOM & Satellite Operations Centre \\
\hline Hammaguir & Algeria & Rocket launch site \\
\hline${ }^{\dagger}$ HartRao (Hartebeeshoek) & South Africa & VLBl; geodesy; radio telescope \\
\hline †High Energy Stereoscopic System (Gamsberg) & Namibia & Gamma ray telescope \\
\hline ISSA - Houwteq (near Grabouw) & South Africa & Satellite testing facility; satellite ground station \\
\hline Kapani Tonneo & Democratic Republic of Congo & Sounding rocket launch site; airstrip \\
\hline †Kottamia Observatory & Egypt & 1.9-m telescope \\
\hline Luigi Broglio Space Centre (near Malindi) & Kenya & Orbital launch pad; satellite ground station \\
\hline †Mauritius Radio Telescope (Bras d’Eau) & Mauritius & Low frequency radio telescope \\
\hline Overberg Test Range (near Arniston) & South Africa & Orbital launch pad; satellite ground station \\
\hline Satellite Applications Centre (near Hartebeeshoek) & South Africa & Satellite ground station \\
\hline †Southern African Large Telescope (near Sutherland) & South Africa & 9-m telescope \\
\hline `Square Kilometre Array & $\begin{array}{l}\text { South Africa plus Botswana, Ghana, } \\
\text { Kenya, Madagascar, Mauritius, } \\
\text { Mozambique, Namibia, Zambia }\end{array}$ & Radio telescope \\
\hline Swakopmund & Namibia & Chinese satellite ground station \\
\hline Tawiwa & Libya & Sounding rocket launch site \\
\hline
\end{tabular}

${ }^{\dagger}$ Astronomy observatories

of such satellite data bought from the market, or in the public domain, we will suffer various drawbacks. Such data are collected according to the needs and priorities of other countries or corporations, and may be subject to limitations in relation to Africa's needs. Data placed in the public domain may also be subject to significant delays and conditionalities. By contrast, an African continental consortium could, for example, negotiate with launch providers to insert a constellation of Earth observation satellites optimally spaced out into a sun-synchronous orbit, ensuring full coverage between Dakar and Djibouti.

It is clear that the necessity for Africa to participate in and coordinate its space activities cannot be overemphasised, and a commitment from developed countries to assist Africa's endeavours, both financially and in knowledge transfer, is vital for the success of our continental space programmes.

\section{Acknowledgements}

The authors would like to thank the Council for Geoscience and the University of the Western Cape for providing the necessary resources towards the writing of this paper.

\section{References}

1. Sharpe C. Space economic readiness - Economic analysis for public funding of space technology in developing African countries [dissertation]. Strasbourg: International Space University; 2010.

2. Martinez P. Space science and technology in South Africa: An overview. African Skies/Cieux Africains. 2008;12:46-49.

3. Jakhu RS. National regulation of space activities. Space Regulations Library. 2010;5:267-314.

4. Gottschalk K. South Africa's space programme - Past, present, future. Astropolitics. 2010;8(1):35-48. http://dx.doi.org/10.1080/14777622.201 0.496528
5. Gottschalk K. South Africa's space heritage: The hidden decade of the 1980s. In: Proceedings of the 62nd International Astronautical Congress; 2011 0ct 3-7; Cape Town, South Africa.

6. Erasmus J. Space science thriving in South Africa. Media Club South Africa [serial on the Internet]. 2011 May 20 [cited 2012 June 12]. Available from: http://www.mediaclubsouthafrica.com

7. Abiodun AA. Future trends in the global arena: Challenges and opportunities for Africa. African Skies/Cieux Africains. 2008;12:12-22.

8. Augustine AA. Africa considers a continent-wide space agency. Science and Development Network [serial on the Internet]. 2010 August 20 [cited 2012 June 18]. Available from: http://www.scidev.net/en/news/africa-considers-acontinent-wide-space-agency.html

9. Regional African Satellite Communication Organisation (RASCOM). Africa's response [homepage on the Internet]. No date [cited 2012 Dec 21]. Available from: http://www.rascom.org/info_detail.php?id_gr $=2 \& i d \_r=25 \& i d$ $\mathrm{sr}=0$ \&langue_id $=2$

10. African Union. 2010 Abuja Declaration [document on the Internet]. c2010 [cited 2012 Dec 21]. Available from: www.africa-union.org

11. Mostert $\mathrm{S}$. The African Resource Management (ARM) satellite constellation. African Skies/Cieux Africains. 2008;12:53-56.

12. NEPAD African Ministerial Council on Science \& Technology. AMCOST Bureau \& Steering Committee [homepage on the Internet]. No date [cited 2012 Dec 21]. Available from: http://www.nepadst.org/steercom/index.shtml

13. African Union. Abuja Declaration 2010. Third Conference of African Ministers in Charge of Communication and Information Technologies; 2010 Aug 3-7; Abuja, Ethiopia.

14. Martinez P. The 2nd African leadership conference on Space Science and Technology for Sustainable Development. African Skies/Cieux Africains. 2008;12:2-11. 
15. United Nations Office for Outer Space Affairs. Capacity building in space science and technology: Regional centres for space science and technology education affiliated to the United Nations [document on the Internet]. c2008 [cited 2012 Dec 21]. Available from: http://cosparhq.cnes.fr/Links/ US00SA_Regional\%20Centres.pdf

16. United Nations Office for Outer Space Affairs. International space law [homepage on the Internet]. No date [cited 2012 Dec 21]. Available from: http://www.unoosa.org/oosa/SpaceLaw/index.html

17. OECD Observer. Space: More than meets the eye [homepage on the Internet]. c2007 [cited 2012 Dec 21]. Available from: http://www.oecdobserver.org/ news/fullstory.php/aid/2316/Space:_More_than_meets_the_eye.html
18. European Commission. Space: International cooperation with Africa [homepage on the Internet]. c2012 [cited 2012 Dec 21]. Available from: http://ec.europa.eu/enterprise/policies/space/esp/internationalcooperation/africa/index_en.htm

19. United Nations Office for Outer Space Affairs. About UN-SPIDER [homepage on the Internet]. No date [cited 2012 Dec 21]. Available from: http://www. oosa.unvienna.org/oosa/en/unspider/index.html

20. Africa Science Technology and Innovation News. African Union launches Pan-African University [homepage on the Internet]. c2011 [cited 2012 Dec 21]. Available from: http://www.africasti.com/lead-stories/african-unionlaunches-pan-african-university

21. Martinez P. Is there a need for an African Space Agency? Space Policy. 2012;28(3):142-145. http://dx.doi.org/10.1016/j.spacepol.2012.06.011 